\title{
Kampanye Pemilu Dialogis untuk Pemilu 2009
}

\author{
Andy Corry Wardhani
}

\begin{abstract}
Political campaign on 2004 was marked by monologue campaigns in the form of mass rally and mass gathering. Information dissemination for the mass was carried out by placing signpost, banners, and pamphlets depicting party's symbol. This kind of campaign belonged to one way communication. Both political party and political leaders were failed to gain feedback from the mass, whereas feedback reflected public's needs and wishes. As consequences, monologue campaigns provide us with low quality campaign oriented toward figures, not their programs. Considering this, a dialogues form of campaign is offered for repairing ineffective political communication between party and people. Dialogical campaigns establish a two-way-communication between party and public, provide ways to clearly communicate problems surrounding the whole situation packaged with party's point of view and its solutions. By conducting dialogical campaign which reflected a-two-way-communication, campaigners and policymakers would benefit from the exchange of public aspirations along the process.
\end{abstract}

Kata kunci: pemilu, kampanye pemilu dialogis

\section{Pendahuluan}

Pemilihan umum ke 9 dalam sejarah Indonesia telah dilakukan pada tahun 2004. Pemilu ini adalah pemilu kedua dalam era reformasi yang dianggap oleh berbagai kalangan sebagai momentum penting dalam rangka membenahi kehidupan politik yang demokratis, sekaligus sebagai langkah awal pemulihan krisis legitimasi pemerintahan. Ada beberapa hal yang menarik dalam pemilu 2004 yang lalu:

Pertama, dari sisi pemilih, rakyat dapat langsung memilih presiden dan anggota legislatif. Kedua, dari sisi pendaftaran pemilih, pemilih secara aktif melakukan pendaftaran di tempat yang ditentukan. Ketiga, dari segi penyelenggaraan, penyelenggaraan pemilu 2004 dilaksanakan secara demokratis, transparan, jujur, dan adil, dengan mengadakan pemberian dan pemungutan suara secara langsung, umum, bebas, dan rahasia.

Berkenaan dengan hal ini, maka penyelenggaraan pemilu dilakukan oleh Komisi Pemilihan Umum (KPU) yang bebas, mandiri dan anggotanya terdiri atas unsur partai politik peserta pemilu dan pemerintah. Pemerintah termasuk TNI tidak lagi diberi kesempatan untuk memihak kepada salah satu peserta pemilu. Bahkan, pemerintah tidak lagi diberi wewenang untuk menjadi pembina politik. Masyarakat, baik domestik maupun internasional, diberi kesempatan seluas-luasnya untuk menjadi pengawas pemilu. Keempat, dari segi pelaksanaan kegiatan kampanye, yaitu diberikannya kedudukan, hak, dan kewajiban yang sama kepada partai politik peserta pemilu selama 
melaksanakan kampanye pemilu dan rakyat diberi kebebasan dan kesempatan untuk menghadirinya.

Upaya bangsa Indonesia menjadikan pemilu 2004 berlangsung secara demokratis, tampaknya tidak menunjukkan kesia-siaan. Hal ini dapat diketahui dari kegiatan Pemilihan Umum Tahun 2004. Pada saat itu, pemberian dan penghitungan suara berjalan sesuai dengan prinsip-prinsip pemilu yang jujur dan adil. Kehidupan demokrasi di Indonesia jauh lebih baik dibandingkan pada pemilupemilu sebelumnya. Adanya kebebasan dalam mengekspresikan pendapat, kerahasiaan, dan kebebasan dalam memberikan suara serta tidak ada lagi intimidasi terhadap masyarakat.

Kehidupan demokrasi yang lebih baik ini, merupakan buah dari jatuhnya rezim Orde Baru pada bulan Mei 1998. Kejatuhan rezim Orde Baru telah mengubah paradigma politik otoritarian ke demokrasi yang ditandai oleh kebebasan pers dan sistem multi partai yang memperluas peran komunikasi dalam aktivitas politik di Indonesia.

Kemahiran berkomunikasi menjadi semakin penting di negara yang menjalankan sistem politik demokrasi atau menuju demokrasi seperti Indonesia. Setiap orang akan bergantung kepada informasi yang diterima dan efektivitas pesan yang disampaikan. Salah satu kemahiran berkomunikasi untuk mendapat dukungan dari masyarakat adalah kegiatan kampanye pemilu.

\section{Komunikasi Politik}

Dalam kehidupan sehari-hari, semua orang, baik pejabat negara, pemimpin partai, maupun warga negara biasa, memerlukan informasi mengenai apa yang terjadi di sekelilingnya, agar ia memeroleh bekal yang cukup untuk mengambil keputusan dalam menjalani agenda hidup masingmasing. Informasi dapat diperoleh bila sistem yang menyebarkannya dapat berfungsi dengan baik, sehingga setiap orang mendapat kesempatan memeroleh apa yang diperlukan masing-masing. Selain itu, informasi tersebut haruslah memenuhi kebutuhan pihak yang membutuhkannya. Salah satu informasi yang dperlukan masyarakat pada waktu pemilihan umum adalah informasi politik.

Informasi politik menyangkut berbagai hal.
Menjelang pemilu masyarakat memerlukan banyak informasi tentang partai politik. Informasi ini penting baginya untuk mengambil keputusan partai mana yang akan dipilih pada saat pelaksanaan pemungutan suara. Pernyataanpernyataan di atas mengajak kita pada studi komunikasi politik.

Komunikasi politik secara sederhana dapat diartikan sebagai proses pertukaran pesan-pesan politik di antara partisipan komunikasi. Secara lebih luas, komunikasi politik diartikan oleh Fagen (1966: 24), sebagai segala komunikasi yang terjadi dalam suatu sistem politik dan antara sistem tersebut dengan lingkungannya. Kajian studi komunikasi politik umumnya berkisar tentang bagaimana peranan komunikasi di dalam fungsi politik. Salah satunya adalah studi yang dilakukan oleh Alfian (1993: 2). Dia menyebutkan bahwa komunikasi politik diasumsikan, sebagai yang menjadikan sistem politik itu hidup dan dinamis. Komunikasi politik mempersambungkan semua bagian dari sistem politik, masa kini dengan masa lampau, sehingga aspirasi dan kepentingan dikonversikan menjadi berbagai kebijaksanaan. Pernyataan Alfian ini, berangkat dari pemikirannya, bahwa komunikasi itu, sebagai gejala politik. Konsekuensi dari pemikiran itu menempatkan komunikasi sebagai akibat dari gejala politik.

Komunikasi bukanlah semata-mata akibat dari gejala politik. Studi yang dilakukan Paul F. Lazarsfeld, Bernerd Berelson, dan Hezel Gandet tahun 1940-an, membuktikan, adanya pengaruh komunikasi terhadap perilaku pemilihan umum di Amerika Serikat. Begitu juga studi komunikasi politik yang dilakukan tahun 1950-an oleh Carl Hovland, Irving L. Jenis, dan Horald H. Kelly, juga membuktikan peranan komunikasi (massa) dalam mengubah opini (politik) masyarakat (Panuju, 1997: 40). Studi-studi yang disebutkan tadi, menunjukkan bahwa gejala komunikasi merupakan variabel bebas (independent variable), dalam arti dia dapat menjadi penyebab terjadinya peristiwa politik.

Kampanye pemilihan umum merupakan salah satu bentuk peristiwa politik yang banyak dikaji dalam studi komunikasi politik. Kampanye pemilu 
dapat dikatakan sebagai bentuk penggunaan teknik persuasi untuk mencapai suatu tujuan. Persuasi adalah suatu usaha untuk mengubah sikap mental, keyakinan, atau perilaku orang melalui transmisi sejumlah pesan.

\section{Kampanye yang Monologis}

Kampanye dapat diartikan sebagai upaya persuasif mengajak orang lain yang belum sepaham atau belum yakin pada ide-ide yang kita tawarkan, agar mereka bersedia bergabung dan mendukungnya. Sejalan dengan pernyataan itu, Dan Nimmo mendefinisikan kampanye sebagai "one form of persuasive communication designed to influence the action of people". (Nimmo, 1990). Sedangkan Rogers dalam Bergner dan Chaffee (1987: 817) menyebutkan kampanye sebagai serangkaian kegiatan komunikasi yang direncanakan sebelumnya yang dirancang untuk menjangkau dan memotivasi orang banyak dengan menggunakan suatu jenis pesan tertentu. Kegiatan kampanye dilaksanakan untuk periode tertentu yang singkat dengan sasaran-saran spesifik berkenaan dengan sikap dan perilaku dan hampir selalu menggunakan suatu pendekatan multimedia.

Berdasarkan ciri-ciri kampanye demikian, kampanye pemilu dapat dikategorikan ke dalamnya, karena pada hakikatnya kampanye pemilu adalah kegiatan yang dilakukan oleh para kontestan pemilu untuk menarik sebanyak mungkin pendukungnya yang pada gilirannya, pendukung ini akan memberikan suaranya kepada partai politik yang menariknya tadi.

Tujuan dari kegiatan kampanye pemilu adalah untuk menentukan penyelenggaraan dari kepemimpinan politik, sebagaimana yang dikemukakan Dan Nimmo "The aim of election campaign is to provide one of the most parties or candidates for developmental of political leadership". (Nimmo, 1970). Lebih jauh, Dan Nimmo merinci 3 tujuan kampanye:

(1) Untuk membangkitkan kesetiaan murni dari para anggota partai agar mereka memilih sesuai dengan harapan partai.

(2) Untuk mengalokasikan suara para warga negara atau masyarakat yang bukan anggota partai agar memberikan suara pada partainya.

(3) Untuk menunjukkan pada partai lain tentang kemampuan calon yang dimunculkan oleh partainya.

Pada kegiatan pemilihan umum tahun 2004 lalu, kampanye cenderung didominasi oleh kampanye monologis. Penyebaran informasi kepada masyarakat dilakukan dalam bentuk pemasangan tanda-tanda gambar atau simbolsimbol partai. Sedangkan kualitas kampanye cenderung tidak bermutu karena berorientasi figur, bukan program. Masyarakat lebih menganggap kampanye sebagai tontonan dan bukan ajang menilai kualitas calon anggota legislatif dan kualitas partai politik.

Apabila dikaitkan dengan makna kampanye dan tujuan kampanye seperti diutarakan di atas, tentu saja pelaksanaan kampanye di Indonesia belum dapat dikatakan berkualitas. Dalam kampanye yang bersifat monologis, komunikasi terjadi satu arah, yaitu dari komunikator ke khalayak. Misalnya melalui pidato, atau orasi dalam rapat umum, atau penyiaran melalui media elektronik. Kampanye pemilu seperti ini terutama dalam rapat umum, tidak dapat dilepaskan dari pengerahan massa dengan pawai besar-besaran. Bagi sebagian anggota masyarakat, terutama kalangan muda, kampanye bagi mereka identik dengan ikat kepala, teriakan liar, naik motor tanpa helm atau menerobos berlawanan arah dan berbagai tingkah laku yang absurd dan vulgar. Substansi pidato kurang mendapat porsi perhatian mereka.

Dalam kerumunan massa, mudah sekali terjadi tindak kekerasan karena etika ribuan massa itu bisa menipis yang disebabkan oleh pengaruh psikologi massa (kesadaran "aku" seketika lenyap di dalam kesadaran "kita"). Dalam situasi seperti ini, rapat akbar dan pawai tidaklah efektif sebagai sarana komunikasi politik. Padahal, komunikasi politik merupakan alat untuk membentuk opini publik. Melalui komunikasi politik, setiap partai politik yang ikut sebagai peserta pemilu mempertahankan atau mengubah opini publik tentang mereka. Dengan demikian, baik buruknya opini umum 
tentang partai politik, tergantung dari kemampuan dari masing-masing partai politik untuk meyakinkan orang banyak.

Dalam rapat akbar, model komunikasi yang digunakan adalah model linier. Khalayak hanya dapat menerima saja informasi atau pesan yang disampaikan komunikator tanpa diberi kesempatan untuk memberi umpan balik. Bentuk komunikasi seperti inilah yang dominan dipraktikkan oleh pemerintah Orde Baru dalam berkomunikasi dengan rakyatnya. Pemerintah Orde Baru terbiasa melakukan monolog, menceramahi, mengarahkan, memerintah, memaksa, memanipulasi, menundukkan dan mengeksploitasi. Menurut Johannesen (1994), dalam monolog pilihan dipersempit dan konsekuensi dikaburkan. Fokusnya terletak pada pesan komunikator, bukan pada kebutuhan nyata khalayak. Pada saat itu, khalayak dianggap benda untuk dieksploitasi semata-mata demi kepentingan dan keuntungan politik si komunikator.

\section{Pentingnya Kampanye Pemilu yang Dialogis}

Respons masyarakat Indonesia terhadap pemilu 2004 lalu cukup baik dan sangat antusias. Hal ini ditandai dengan banyaknya masyarakat yang datang ke tempat-tampat pemungutan suara. Dalam kampanye pun mereka menunjukkan perhatian yang besar, terutama dalam pawai dan rapat akbar. Pada hakikatnya, dalam kampanye setiap orang dapat memeroleh berbagai pesan, informasi, dan kesan tentang partai politik peserta pemilu, sehingga dia dapat menentukan hak pilihnya terhadap salah satu partai politik sebagai penyaluran aspirasi politiknya. Kemudian pada waktu yang telah ditentukan, orang tersebut dapat mencoblos atau menusuk tanda gambar partai politik peserta pemilu idamannya. Di tempat pemungutan suara secara langsung, umum, bebas dan rahasia. Pelaksanaan pemilu dilakukan berdasarkan prinsip-prinsip pemilu yang jujur dan adil. Dengan demikian, dapat dipahami betapa pentingnya peranan kampanye pemilu dalam menentukan pilihan seseorang terhadap salah satu partai politik peseta pemilu. Oleh karena itu, wajarlah terjadi persaingan di antara partai politik peserta pemilu untuk merebut simpati dan dukungan suara sebanyak-banyaknya dari masyarakat atau khalayak untuk memenangkan pemilu.

Mengamati dan mempelajari pengalaman kampanye pemilu tahun 2004 lalu di Indonesia, seperti yang telah dijelaskan sebelumnya, dapat diungkapkan bahwa kampanye yang dilakukan, disadari atau tidak disadari, ternyata belum dapat dikatakan berkualitas, karena masih berorientasi kepada figur ketua partai, bukan program yang akan diperjuangkan partai. Selain itu, bentuk kampanye cenderung didominasi kampanye monologis. Dalam kampanye monologis, sengaja atau tidak disengaja, sering menimbulkan kritikan, perbedaan pendapat yang menjurus kepada celaan pada pihak lain, sehingga membawa dampak hubungan antarindividu maupun kelompok yang kurang harmonis. Hal ini dapat terjadi karena fokusnya pada kepentingan komunikator bukan kebutuhan nyata khalayak. Khalayak dianggap benda yang tidak memungkinkan memberikan umpan balik. Dalam kondisi seperti ini, jangan diharapkan adanya pendidikan politik bagi khalayak. Khalayak tidak dapat menilai kualitas calon anggota legislatif dan kualitas partai politik.

Kelemahan lain dalam kampanye monologis, terutama yang berbentuk rapat umum, adalah dalam hal peserta kampanye, yang biasanya warga partainya sendiri, serta melarang orang lain (bukan anggota partai yang berkampanye) untuk masuk ke arena kampanye. Sebenarnya untuk apa meyakinkan orang yang memang sudah pasti akan memilih partai yang kita pimpin? Kita butuh meyakinkan orang lain. Tujuan kampanye akan tercapai, bila kita berbicara di hadapan orang yang belum tentu akan memilih partai kita.

Fenomena lain yang menarik diungkapkan, yaitu ketika partai politik melakukan kampanye dialogis, namun pesertanya adalah pendukung partai itu sendiri, sehingga tidak mengherankan pertanyaan yang dilontarkan sesungguhnya sudah disusun terlebih dahulu. Begitu juga jawabannya seperti skenario sinetron. Kampanye seperti ini tidak akan memberikan pengaruh apa-apa kepada 
khalayaknya. Apabila sandiwara ini, diketahui oleh masyarakat lain, bisa menjadi counter-productive terhadap partainya sehingga bukan simpati dan dukungan yang akan diperolehnya melainkan pengalihan suara.

Berdasarkan catatan-catatan di atas, dan memperhatikan selama kampanye pemilu tahun 2004 lalu di Indonesia yang cenderung mengambil bentuk pengerahan massa, atau diskusi terbatas pada kader partai sendiri, maka perlu dipertimbangkan bentuk kampanye dialogis pada pemilu tahun 2009 yang akan datang.

Martin Buber (1970) memandang dialog sebagai inti komunikasi. Menurutnya, dialog merupakan hubungan Saya-Anda (I-Thou), yaitu manusia dengan manusia, yang ditandai dengan kebersamaan, keterbukaan hati, kelangsungan, kejujuran, spontanitas, keterusterangan, tidak pura-pura, tidak manipulatif, kerukunan, intensitas, dan cinta kasih dalam arti bertanggung jawab kepada orang lain. Dialog berbeda dengan komunikasi Saya-Benda (I-It) atau komunikasi monologis yang ditandai dengan cinta diri, penipuan, kepura-puraan, kelicikan, dominasi, eksploitasi, dan manipulasi.

Dalam kampanye pemilu, bentuk dialogis merupakan bentuk kampanye yang sudah saatnya dilakukan, untuk memberikan pemahaman tentang suatu masalah kepada masyarakat dan cata-cara yang ditawarkan untuk mengatasi masalah tersebut. Sesuai dengan perkembangan kecerdasan dan semakin kritisnya masyarakat, mereka menghendaki pandangan yang bersifat investigatif dan argumentatif. Hal ini relevan dengan definisi dasar dari kampanye yang menghendaki upaya persuasif daripada represif. Disamping itu, bentuk dialogis yang menghasilkan komunikasi dua arah, sangat tepat untuk menjaring aspirasi masyarakat, dan dapat dengan cepat mengartikulasikan aspirasi itu sehingga lebih mudah dipahami oleh pembuat kebijaksanaan publik. Dialog di sini bukan antara tokoh atau kandidat dengan kader partainya sendiri, melainkan melibatkan tokoh dan kader antarpartai, di hadapan publik yang tidak hanya terdiri dari para kader partai yang sedang berdialog.
Dialog tidak hanya dapat dilakukan secara konvensional, tetapi juga bisa dilakukan dengan memanfaatkan teknologi mutakhir, yaitu dengan menggunakan media massa. Media massa sangat membantu partai politik atau kandidat partai untuk menyebarluaskan ide atau pandangan mereka secara luas dalam masyarakat yang terdiri atas berbagai segmen. Jenis media audio-visual, seperti televisi merupakan pilihan terbaik, karena selain dapat didengar juga visualisasi orang berbicara akan sangat membantu calon pemilih, memahami posisi satu partai atau kandidat terhadap isu yang berkembang. Televisi saat ini, tidak saja menyiarkan program partai, tetapi penonton pun dapat memberikan umpan balik melalui telepon. Dengan demikian komunikasi dua arah tetap bisa tercipta.

Kampanye dialogis sebagai sarana untuk mendapat dukungan khalayak, memerlukan perencanaan yang matang dalam pelaksanaannya. Dan Nimmo (1970) dalam bukunya The Political Persuaders, menyebut beberapa langkah-langkah yang perlu diperhatikan.

1. Allocate the campaign management, yaitu menentukan manajemen kampanye yang merupakan suatu kegiatan mengatur kegiatan kampanye mulai dari pengumpulan data, pengolahan data, sampai pada pengorganisasian dan evaluasi hasil. Manajemen kampanye terdiri atas tahap-tahap kegiatan:

a. Allocate the campaign structure organization, yaitu menentukan struktur organisasi kampanye untuk memberikan kejelasan tentang status, tugas, wewenang, dan tanggung jawab yang ada dalam lingkup struktur, sehingga setiap anggota yang ditunjuk dalam kegiatan kampanye jelas deskripsi tugasnya. Struktur organisasi kampanye itu tersusun sebagai berikut:

1) Campaign managers. Seorang manajer kampanye yang bertugas mengelola segala aspek yang berkaitan dengan kampanye, yaitu dengan:

a) Memberikan ide tentang kampanye yang seharusnya dilakukan.

b) Membuat naskah kampanye. 
c) Menentukan tema dan slogan kampanye.

d) Menentukan juru kampanye (campaign master).

e) Menentukan suatu posisi tindak lanjut apabila ada counter atau balasan dari partai lain.

2) Campaign consultans, yaitu konsultan kampanye yang menangani kegiatan penelitian terhadap pendapat umum. Para konsultan polling ini bertugas memantau sampai sejauhmana kecenderungan pendapat umum dapat diarahkan pada kondisi yang dapat mendukung keberhasilan kampanye. Selain itu, konsultan kampanye juga bertugas mengumpulkan data tentang respons masyarakat terhadap isu-isu yang mereka terima, apakah respons itu bersifat positif atau negatif.

3) Technical special, yaitu pelaksana kampanye yang terdiri atas:

a) Devicing advertising message, yaitu petugas yang menangani pesan dan bentuk periklanan.

b) Making television commercials, yaitu petugas yang menyelenggarakan televisi komersial.

c) Fund raising, yaitu para donatur partai.

d) Speech writers, yaitu penulis naskah kampanye.

e) Coaching the candidate in public appearances, yaitu para pelatih kandidat yang akan tampil dalam kampanye.

b. Planning the campaign, yaitu persiapan matang yang dituangkan ke dalam formulasi perencanaan di berbagai aspek. Jenis kegiatannya sebagai berikut:

1) Perencanaan tentang jadwal dan waktu kegiatan kampanye.

2) Perencanaan tentang lokasi kampanye.

3) Perencanaan tentang sasaran kampanye.

4) Perencanaan tentang metode dan sarana yang akan digunakan

5) Perencanaan tentang penentuan juru kampanye.
2. Choosing the campaign masters, yaitu juru-juru kampanye yang telah dibekali berbagai materi yang diolah sesuai dengan kemampuan imajinasi mereka. Syarat utama bagi juru kampanye adalah kemampuan menstranfer produk-produk imajinasi ke dalam kata-kata yang dapat memotivasi rakyat ke tempat pemilihan dengan suara yang ditunjukkan kepada partainya. Juru kampanye itu dapat seorang politisi dari pimpinan partai, juru kampanye profesional, tenaga sukarela atau calon terpilih.

Langkah-langkah kampanye yang dikemukan Dan Nimmo di atas, merupakan hal mendasar yang harus dilakukan untuk menjadikan kampanye itu efektif. Hal ini semakin penting bila dikaitkan dengan perubahan paradigma politik yang dialami Indonesia. Perubahan paradigma itu, memengaruhi pula praktik-praktik politik, termasuk di dalamnya cara bagaimana orang menghimpun dukungan. Pada kekuasaan otoritarian, praktik kekerasan merupakan hal yang lumrah. Ketika kekuasaan berubah dan praktik politik mengarah kepada pelaksanaan demokrasi, praktik politik kekerasan digantikan dengan seni persuasi. Mekanisme populer dalam praktik kekuasaan otoriter adalah penggunaan aparat keamanan untuk keperluan penguasa, sedangkan dalam sistem politik yang demokratis, dukungan publik terhadap sistem kekuasaan ditempuh melalui proses persuasi dengan mengandalkan seni dan keterampilan mengelola komunikasi. Kajian ini adalah satu di antaranya, bagaimana cara kita mengelola komunikasi, yang bermanfaat bagi partai politik di Indonesia.

\section{Penutup}

Berdasarkan uraian pada bagian-bagian sebelumnya, dapat ditarik kesimpulan dan saran sebagai berikut:

(1) Kemahiran berkomunikasi menjadi semakin penting di negara yang menjalankan sistem politik demokrasi atau menuju demokrasi seperti Indonesia. Setiap orang akan bergantung kepada informasi yang diterima 
dan efektivitas pesan yang disampaikan. Salah satu kemahiran berkomunikasi untuk mendapat dukungan dari masyarakat adalah kegiatan kampanye pemilu.

(2) Kampanye pemilu tahun 2004 di Indonesia, cenderung didominasi oleh kampanye monologis. Penyebaran informasi kepada masyarakat dilakukan dalam bentuk pemasangan tanda-tanda gambar atau simbolsimbol partai. Sedangkan kualitas kampanye cenderung tidak bermutu karena berorientasi figur, bukan program. Masyarakat lebih menganggap kampanye sebagai tontonan dan bukan ajang menilai kualitas calon anggota legislatif dan kualitas partai politik. Dalam kampanye yang bersifat monologis, komunikasi terjadi satu arah, yaitu dari komunikator ke khalayak.

(3) Berdasarkan catatan-catatan kampanye pemilu tahun 2004 lalu di Indonesia, yang cenderung mengambil bentuk moologis; pengerahan massa dalam rapat-rapat umum dan diskusi terbatas pada kader partai sendiri, maka perlu dipertimbangkan dominasi bentuk kampanye dialogis untuk pemilu tahun 2009 yang akan datang. Bentuk dialogis merupakan bentuk kampanye yang sudah saatnya dilakukan, untuk memberikan pemahaman tentang suatu masalah kepada masyarakat dan cata-cara yang ditawarkan untuk mengatasi masalah tersebut. Sesuai dengan perkembangan kecerdasan dan semakin kritisnya masyarakat, mereka menghendaki pandangan yang bersifat investigatif dan argumentatif. Selain itu, bentuk dialogis yang menghasilkan komunikasi dua arah, sangat tepat untuk menjaring aspirasi masyarakat, dan dapat dengan cepat mengartikulasikan aspirasi itu, sehingga lebih mudah dipahami oleh pembuat kebijaksanaan publik. Dialog di sini, melibatkan tokoh dan kader antarpartai, di hadapan publik yang tidak hanya terdiri atas para kader partai yang sedang berdialog.

Perkembangan politik di Indonesia, telah mengarah ke bentuk demokratis. Perkembangan politik tersebut, memerlukan perubahan strategi dalam memeroleh dukungan publik terhadap partai politik atau politisi. Di masa lalu, kekuatan politik yang ingin mendapat dukungan publik, dapat mengandalkan pelbagai cara yang dianggap keras, seperti pengarahan massa secara besar-besaran dalam rangka show offorce. Strategi seperti ini tidak lagi dianggap efektif, bila dilihat dari perkembangan politik dan perkembangan kecerdasan masyarakat. Oleh karena itu, sebagai saran, hendaknya saat ini mereka harus mau secara sabar mendengarkan suara publik/massa melalui dialog maupun polling yang diadakan oleh mereka atau pihak lain. Berdasarkan hasil dialog maupun polling ini, dapat diketahui apa keinginan dan keprihatinan para pemilih. Berdasarkan temuan-temuan di lapangan, mereka harus menyusun platform partai dan tokoh politiknya, menawarkan program, serta membangun citra partai sesuai yang diinginkan publik. Kesemuanya ini memerlukan komunikasi, karena itu setiap partai politik harus menyiapkan departemen komunikasi dan manajer komunikasi untuk memimpinnya. Apabila upaya ini dilakukan oleh partai politik di Indonesia, kita akan dapat melihat bentuk kampanye yang berkualitas.

\section{Daftar Pustaka}

Alfian. 1993. Komunikasi Politik dan Sistem Politik Indonesia. Jakarta: Gramedia Pustaka Utama.

Berger, Charles R, Chaffee, Steven H. 1987. Handbook of Communication Science. California: Sage Publications.

Buber, Martin. 1970. I and Thou. New York: Charles Scribner's Sons.

Fagen, R.R. 1966. Politics and Communication. Boston: Little Brown and Company. 
Johannesen, Richard L. 1994. Ethics in Human Communication. Edisi ke-3. Prospect Heights, III: Waveland Press.

Nimmo, Dan. 1970. Political Persuaders. New York:

\section{Prentice Hall.}

Panuju, Redi. 1997. Sistem Komunikasi Indonesia. Yogyakarta: Pustaka Pelajar. 